\title{
A SPATIAL ANALYSIS OF THE FRIDA KAHLO MUSEUM IN THE CONTEXT OF INFORMATION SHARING BEHAVIOR VIA SOCIAL MEDIA
}

\author{
Nuran IRAPOĞLU \\ Istanbul Technical University, Istanbul, Turkey, \\ irapoglu19@itu.edu.tr \\ https://orcid.org/0000-0001-6097-7364 \\ Hande Nur GÜLEÇOĞLU \\ Istanbul Technical University, Istanbul, Turkey, \\ handenur.gulecoglu@itu.edu.tr \\ https://orcid.org/0000-0003-2148-3032 \\ Büşra TOPDAĞI YAZICI \\ Karadeniz Technical University, Trabzon, Turkey, \\ busratopdagi@ktu.edu.tr \\ https://orcid.org/0000-0003-1203-4411
}

\begin{tabular}{|c|l|}
\hline \multirow{3}{*}{ Atıf } & $\begin{array}{l}\text { Irapoğlu, N., Güleçoğlu, H. N. ve Topdağı Yazıcı, B. (2021). A SPATIAL ANALYSIS OF } \\
\text { THE FRIDA KAHLO MUSEUM IN THE CONTEXT OF INFORMATION SHARING } \\
\text { BEHAVIOR VIA SOCIAL MEDIA. The Turkish Online Journal of Design Art and } \\
\text { Communication, 11 (4), 1388-1402. }\end{array}$ \\
\hline
\end{tabular}

\begin{abstract}
Since internet has become widely available, various mediums have emerged that people could produce their content on. Through these mediums, an opportunity rose that was to communicate independently from the space and thus, information sharing behavior has been observed among colleagues, students, communities, and institutions. It was possible to observe that this behavior increased during the pandemic process. This study is mainly aimed to discuss how space and art became instrumental in these shares and to discuss the relationship between spatial configuration and shares through museums. Another aim of the study can be described as to reveal the differences of spatial elements shared on social media at the end of the real and virtual museum experience with space syntax analysis. In this context, data were obtained from the Frida Kahlo Museum. The data collected were listed according to the frequency of sharing, and spots were identified in the museum plan. Integration values of these points in the Space Syntax 2D software were determined. The relationship between spatial configuration and frequency of sharing has been revealed. As a result, it has been determined that the sharing status of the Frida Kahlo Museum's elements is associated to the spatial configuration in sharing contents of the real experience. Besides, it has been determined that the semantic features of the space are associated. In contrast, during the virtual experience, it has been observed that the spatial configuration is not directly associated to the sharing frequency. It was observed that objects of art and daily life directed more sharing behavior. In this study, which examines the behaviors of virtual and real museum visitors, the effort to reveal the connection of space with information sharing is the original idea of the study.
\end{abstract}

Keywords: Information Sharing Behavior, Museum Experience, Social Media, Space Syntax, Frida Kahlo. 


\title{
FRİDA KAHLO MÜZESI'NIN SOSYAL MEDYA ÜZERİNDEN BİLGİ PAYLAŞMA DAVRANIŞI BAĞLAMINDA MEKANSAL ANALIZİ
}

\begin{abstract}
ÖZ
İnternetin yaşamımıza girmesinden bu yana insanların içeriklerini kendilerinin ürettiği mecralar ortaya çıkmıştır. Bu mecralar aracılığıyla mekandan bağımsız iletişim kurma olanakları ve dolayısıyla, meslektaşlar, öğrenciler, topluluklar, kurumlar arasında bilgi paylaşım davranışı görülmeye başlanmıştır. Pandemi sürecinde ise bu davranışın arttığını gözlemlemek mümkün olmuştur. $\mathrm{Bu}$ çalışmada, esas olarak mekan ve sanatın bu paylaşımlarda nasıl araçsallaştı̆̆ ve mekansal konfigürasyon ile paylaşımlar arasındaki ilişkiyi müzeler üzerinden tartışmaya açmak hedeflenmiştir. Çalışmanın bir diğer amacı, gerçek ve sanal müze deneyiminin sonunda paylaşılan ilgi çekici mekansal unsurların space syntax analizi ile farklılıklarını ortaya koymak olarak nitelendirilebilir. Bu bağlamda Frida Kahlo Müzesinden veriler elde edilmiştir. Toplanan veriler paylaşım sıklıklarına göre listelenerek müze planında noktalar belirlenmiştir. Bu noktaların Space Syntax 2D programında integration değerleri belirlenmiştir. Mekansal konfigürasyon ve paylaşım sıklığı arasındaki ilişki ortaya konmuştur. Sonuç olarak Frida Kahlo müzesinin ögelerinin paylaşım durumunun gerçek deneyim paylaşımlarında mekansal konfigürasyonla bağlantılı olduğu ayrıca mekanın semantik özelliklerininde etkili olduğu tespit edilmiştir. Sanal deneyim sırasında ise mekansal konfigürasyonun paylaşım sıklığ ile doğrudan bağlantılı olmadığı, günlük yaşama dair nesnelerin ve sanat eserlerinin paylaşım davranışını daha çok yönlendirdiği gözlemlenmiştir. Sanal ve gerçek müze ziyaretçilerinin davranışlarının incelendiği bu çalışmada, mekanın bilgi paylaşımıyla bağlantısının ortaya konulması çabası çalışmanın özgün yönüdür.
\end{abstract}

Anahtar Kelimeler: Bilgi paylaşma davranışı, müze deneyimi, sosyal media, Space Syntax, Frida Kahlo.

\section{INTRODUCTION}

The rapid input of computers into people's workplaces, homes, education, and health environments has not only changed the physical landscape of interiors but has also enabled the establishment of highspeed digital communication networks that fundamentally facilitate the limitation of time and physical distance on many forms of social interaction (Stokol and Montero, 2002: 661). Since the internet has entered our lives, we have found new mediums that have helped people produce their content. Through various applications (such as Facebook, YouTube, Twitter, Pinterest, TripAdvisor, Blogger...) new behaviors were developed in relationships with other people virtually. In this direction, the opportunity to communicate independently of the place has emerged. Thus, information sharing behavior has started to be observed among colleagues, students, communities, and institutions. It was possible to observe that this behavior increased during the pandemic process.

This study is mainly aimed to discuss how space and art become instrumental in these shares and to discuss the relationship between spatial configuration and shares through museums. This study has emerged from questions such as "Can architecture be associated with factors affecting information sharing behavior?" or "Can architecture be one of these factors?" and in this sense, "What can be the differences of virtual and real experience?" Another aim of the study can be described as to reveal the differences of spatial elements shared on social media at the end of the real and virtual museum experience with space syntax analysis.

Previous research has shown that the choice of medium for information sharing and searching rely on the desired information topics and types (Liu and Jansen, 2012; Williamson et al., 2012), users' previous experience with other media (Lee and Ma, 2012), and motivating or hindering factors (Syn and Oh2015; Hsu et al., 2007). In the study, which deals with implicit and explicit knowledge in architecture, the effect of space syntax theory and physical space experience on information sharing has been revealed

Submit Date: 12.07.2021, Acceptance Date: 17.08.2021, DOI NO: 10.7456/11104100/013

Research Article - This article was checked by iThenticate

Copyright (C) The Turkish Online Journal of Design, Art and Communication 
(Appel-Meulenbroek, 2009). It is possible to overlap the syntactic and semantic features of the space in the experience of museum spaces (Şalgamcioğlu and Cababak, 2017) and transformed buildings (Okuyucu and Çoban, 2021). At this point, the semantic features of the space come from the information-sharing behavior of the people. Its syntactic feature arises from syntactic calculations that draw a logical framework built on fields of view called isovist (Benedikt, 1979). Syntax 2D software of the University of Michigan was used for analysis. For the purposes of this study, real and virtual museum experience has been examined through the Frida Kahlo Museum, Twitter, and TripAdvisor.

In this context, data were obtained from the Frida Kahlo Museum Because it was observed that the virtual museum attracted intense interest during the pandemic period. Later obtained statistical data shows that, on these dates, the frequency of the virtual tour visitors was relatively high (including users participating from Turkey). In addition, the sharing of the works of art, the words attributed to her, her life story on the social media of Frida Kahlo, and the fact that the house museum has scenes preserved from her real life support the reason for the choice.

After determining the general spatial features of the museum, in 2020, real museum experience shares before the pandemic were collected from shared images on TripAdvisor, and virtual museum experience shares during pandemic were collected from shared images on Twitter. The data collected were listed according to the frequency of sharing, and spots were identified in the museum plan. Integration values of these points in the Space Syntax 2D program were determined. The relationship between spatial configuration and frequency of sharing has been revealed.

\section{THEORETICAL BACKGROUND: Information Sharing Behavior, House Museum}

\section{Information Sharing Behavior and It's Motivations}

Today, since the state of obtaining information related to mainstream media has changed, the introduction of social media has also changed the flow of information regarding important developments, and the behavior of seeking, sharing, and consuming information (Lee and Ma, 2012). In addition to social media platforms such as Facebook, Twitter, Instagram, new media, such as web pages, blogs, photo, and video sharing sites, whose content is developed by users, has become one of the most important communication tools of today. Thousands of videos, photos, narratives, and similar content are shared in a very short time regarding the development in any part of the World (Yıldizgörür, 2018: 53). This changed the habits of acquiring and disseminating information through traditional mass media. So much so that in recent years, the concepts of sharing or sharing with the effect of social media, means information exchange for users on social media (Van Dijck, 2013: 65). When asked the question of why people share on social media or the internet, information sharing behavior comes to the agenda. As part of the communication process, sharing behavior is very common for the social media environment, because social media users are active participants, not passive audiences. According to Gollant and Boone (2012), sharing is an implicit part of media consumption for social media users (Y1ldıgörür, 2018: 53).

Generally, the term information sharing is used to express the information transfer between individuals or organizations. (Alakurt and Keser, 2015: 1036). In this case, it would not be wrong to say that every sharing that people make on social media or the internet causes the production/transfer of information. Although the factors that motivate information sharing behavior can be increased (Chang and Chuang, 2011), it consists of 10 items according to Oh and Syn (2015: 558-9):

-Enjoyment: As a major factor of motivation, previous studies have shown that social media users are likely to participate and contribute to social media when they have fun.

-Efficacy: Users tend to share information they think others will like or believe may be useful. Previous studies have shown that people share information via Twitter to recognize more out-of-sight

Research Article - This article was checked by iThenticate 
content that they think informative and worthy because they act as curators (Oh and Syn, 2015). TripAdvisor is also used very effectively with this motivation as it is mostly a platform focused on recommending the most suitable and experienced commercial venues.

-Learning: One of the most important reason for users to join a community is to learn something new. Users desire to learn stimulates them to find information and share it with others.

-Personal Gain: It is possible that the users actively share the information when they think that they are getting a personal benefit from sharing. According to previous studies, they may tend to share their work to develop the business, earn one's own, and earn a person's profession or other financial income.

-Altruism: People sometimes share without any beneficial outcome. People spread information as an act of curation.

-Empathy: People can be motivated by empathy to help others find the information they need. People share information to give a voice to less popular people as an act of friendship.

-Community interest: Being in a social networking environment, in a network or community, encourages users to be motivated by the goals and values of communities. Therefore, they may be interested in supporting society by sharing information. The concept of belonging to a community is the most important factor at this point.

-Social Engagement: Users would like to be connected to others. Such a desire can encourage people to communicate with others by sharing information.

-Reputation: In a social network, users unconsciously value the sense of fame. According to previous studies, values stemming from the desire for popularity can encourage users to share.

The fact that seeing a new place and an architectural experience of it are often enjoyable and instructive, it enables information sharing to take place. At the same time, the high number of people interested in these experiences encourages the users who share, based on these motivations. Because reaching more people increases the effect of sharing. In addition, space is perceived in society and its different in eyes of others so this helps to express the space differently from person to person thus the space viewed will have an identity from the viewers perspective. In this sense, architecture is at a point that affects and also mediates information-sharing behavior.

In architecture, the semantic value of space can be addressed not only because it refers to certain functions, but also because of the symbolic character that the general object assumes in the way, it reveals itself and its structure (Eco, 1989). Because, mostly, the semantic effect of these specific messages relies on the level of awareness we carry to the system of contextual connections. Therefore, it reveals the potential of the studies that can be carried out between the two disciplines with the wide sphere of influence of the fields of architecture and communication. It has been seen that these are dealt with interpersonal communications, in the field of application of the profession, in the media, and technological and technical developments (Irapoğlu, 2019: 36). At this point, in this study, museums have been deemed worthy of discussion to deepen their relationship with communication, information sharing behavior, and architecture.

It is possible to discuss this subject with the help of museum spaces where architectural space and artwork can be handled together. Just as museums use social media for promotion (Üstünipek, 2013), people use social media through museums. Because of the factors that motivate information-sharing behavior, museums are interesting and have the potential to reach more people. It is also an opportunity

Research Article - This article was checked by iThenticate 
to observe the effect of virtual tours in this context. (The fact that people spend their time in their homes due to the Covid19 pandemic has affected the approach of the study in this direction.) Virtual museum spaces are obtained by transferring a concrete entity made up of stones into an abstract medium produced from "bytes" that make up the invisible infrastructure of computer programs. They are environments that cannot be handled, but where the spirit of the place is perceived virtually. Benedikt states that virtual space possesses a style, identity, and working reality as well as possessing the features of physical space. In addition, he says that the virtual space has a nature and law in the geography it belongs to and that it can offer the possibilities provided by the physical space (Benedikt, 1991).

In addition, the most shared architectural and artistic elements are assumed to be the most interesting in the context of information sharing behavior of people. At this point, the Frida Kahlo Museum, which has been transformed from the house of the painter Frida Kahlo, with its original and radical works, is discussed. The museum was deemed worthy of consideration in terms of having traces of the artist's life, hosting many works of the artist and its interest.

\section{House Museum}

The word museum is described as "the place or structure where art and science works or objects used for art and science are stored and exposure for public display" (TDK, 2020). According to the International Council of Museums (ICOM), the museum is non-profit, works for the development and service of the society, and includes public and permanent elements; is an institution that collects, stores, researches, transmits, and displays the material evidence of human and its environment for study and educational purposes.

While in an old school of thought it was enough to construct a building and arrange it with collections about the past, recently the idea of using the places where literary, musical and political geniuses lived as museums has emerged. In this context, the work of the Committee of Historic House Museums (DEMHIST) within ICOM stands out. According to DEMHIST, house museums are structures that have been opened to the public today, used as dwellings reminiscing the past, containing the original furniture of historical buildings, and showing their historical and cultural collections. It is also defined as a special museum type that reflects the spirit of famous creators and is connected to the historical memories of a community (ICOM, 2020).

Historic House Museums are places belonging to people who have left a mark in a period or social history, which constitutes integrity with its architectural features, interior arrangements, fixed and movable furniture, and the items used in it. In addition, they can also be considered as museums where people live for a certain period, collection materials for their daily lives are exhibited, and information about that person's character, life, and what they do (Uz,2010).

According to Gaston Bachelard (2014), every place in which there is a real residence contains the essence of the concept of the house. The house contains the dream, protects the dreamer; the house allows us to dream in serenity. Indicators of gains in human life are household objects, and the house is their container. Items protect historical information. Each object is linked to a past event, person, or time. Items can be thought of as a memory that embodies and materializes the past. Each object in the house is also an indicator of social life, the historical process of the society, and the economic situation of the society in which it is located.

The objects in the space are the indicators of the identities living in the house. They are tools for emphasizing individual identities. Objects transmit the thoughts of the individual to the person coming to the house. On the other hand, the visitor who stops by a house can learn about the individual in line with this conveyed message, while observing the house within this framework. House museums can contribute to the preservation of original pieces that form social memory based on personal data. The purpose of the house museum is to convey the life at the house to the museum visitor in the most accurate

Research Article - This article was checked by iThenticate 
way. In historical house museums, the place itself is considered as an exhibition area with its collection and architectural features. For this reason, it has a distinctive feature from other museums.

\section{METHODOLOGY: Case Study, Data Collection, Data Analysis}

In this study, which aims to discuss how space and art become a tool in social media sharing and the relationship between spatial configuration and sharing through museums, Frida Kahlo museum was chosen as a case study. The study began with questions such as: "Can architecture be associated with factors influencing knowledge sharing behavior?", "Could architecture be one of these factors?" And, netnographic approach was adopted as the data collection technique. Space Syntax theory was used to implement a spatial analysis.

The methodological approach that brings together the relationship between virtual and real museum experience and information sharing behavior with netnography technique and space syntax analysis at the Frida Kahlo Museum constitutes the original point of this study. The fact that it creates a basis for discussing the syntactic and semantic features of the space together shows the importance of the study.

\section{Case Study: The Frida Kahlo Museum / Casa Azul}

Frida, whose real name is Magdalena Carmen Frida Kahlo y Calderón, was born on July 6, 1907. Frida lived in her room for nine months as she contracted polio at the age of six. When she was eighteen, she had a tram accident. After this accident, all her life is spent in corsets, with hospitals for many surgeries. Frida suffered emotionally and physically as a result of the accident. Frida kept in bed for a long time and had a series of operations. After the accident, Frida's interest in painting increased. She spent most of her life painting self-portraits, thanks to the mirror placed by her mother on a wooden bed made specially by her family. In the recovery phase, she has begun to get closer to the art and policy circles. She met Mexican painter Diego Rivera through her friend Tina Modotti and married in 1929. But Frida's body, which was in pain throughout her life, was emotionally devastated this time due to Diego's unfaithfulness. Frida has been painting with all her strength to deal with the unbearable pain in her body for most of her life. She has opened several exhibitions in Mexico, America, and France. Especially the New York exhibition in 1938 brought her great reputation. Frida and Diego taught for 10 years at a private art school called Esmeralda, which opened in 1942. Frida Kahlo, one of the great artists of the 20th century, revealed her inner world and her struggle against life, and her turbulent relations with auto portraits and words. On July 13, 1954, she left us at her home in Coyoacán, where she was born (Herrera, 2018).

Her house, known as Casa Azul (Blue House), was turned into a museum 4 years after her death. Casa Azul is one of the most popular museums of the Mexican capital today. After marrying Diego Rivera, Frida has always returned to her home, even though she lives in Mexico City and abroad in different places. This house is her creative universe. The museum displays the bed of Frida Kahlo, the mirror she paints, and the kitchen she cooks with Diego. In addition, the museum contains 22 thousand documents, 6,500 photos, magazines and periodicals, books, dozens of drawings, personal items, clothes, toys, and clues about the life of Frida and Diego (URL1, URL2).

Although it has been 66 years since Frida Kahlo's death, she still impresses many people with her life story and works. In social media and the virtual world; works of art, words attributed to her, her life story are researched, shared, and liked by the masses. Nowadays, it is known that people worldwide remain in quarantine because of the "Covid 19 pandemic". During the pandemic days, the internet is used as the only way to see the works of many world-famous artists. According to the statistics on artists that have been searched the most in 2020 and the most popular artists in each country, Kahlo was the most searched artist in Turkey (Figure 1) (URL3). 


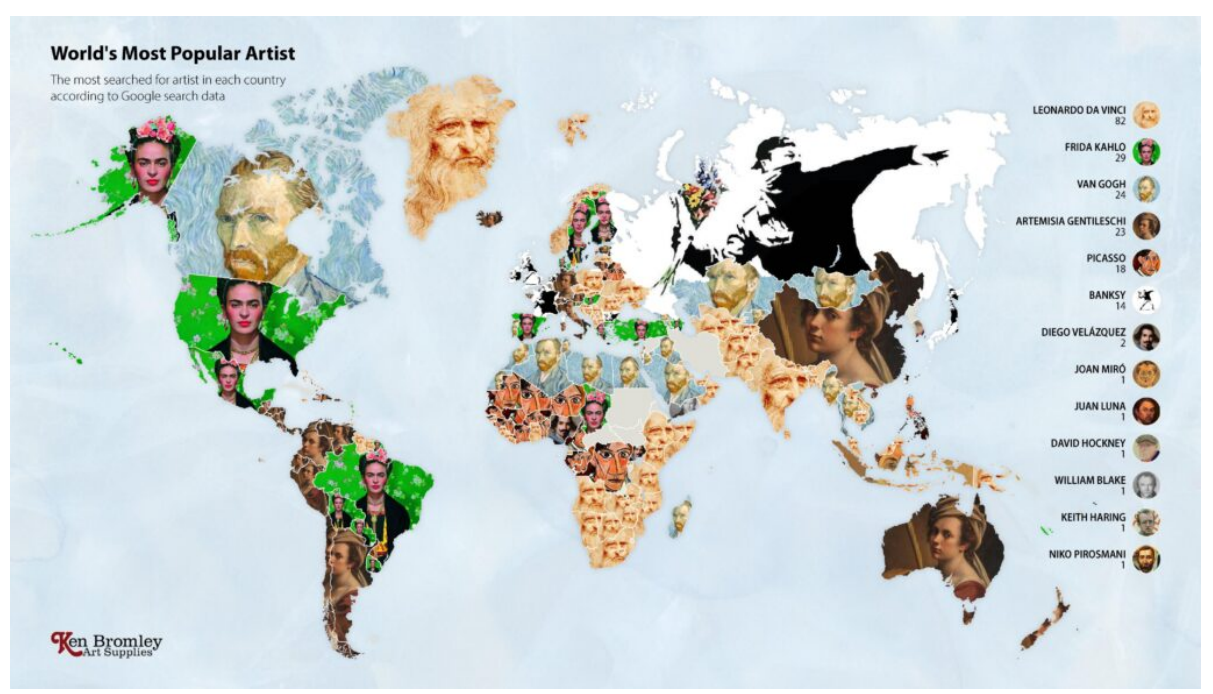

Figure 1. Map of World's Most Popular Artist

Reference: (URL-3).

Due to quarantine, the news of Frida Kahlo's Museum house opening to visitors in a virtual environment has taken place in the media (both mainstream media and social media) to a large extent. As a result of the online visit of Casa Azul, has made it possible to realize that even a museum can be experienced virtually by people sharing it on social media, and as a result, places or objects with attractions can be selected and published. And also, according to the data from the company that created the virtual tour of the Frida Kahlo museum, there has been a noticeable increase in the number of visitors in the last three months. Also, according to the statistics received, Virtual tour was visited quite a high percentage by the participating users from Turkey (Figure 2). It was observed that $22 \%$ of the visitors to the site reached the site via social media. Therefore, as a consequence of these periodic effects, and our purpose of working focused on Frida Kahlo.

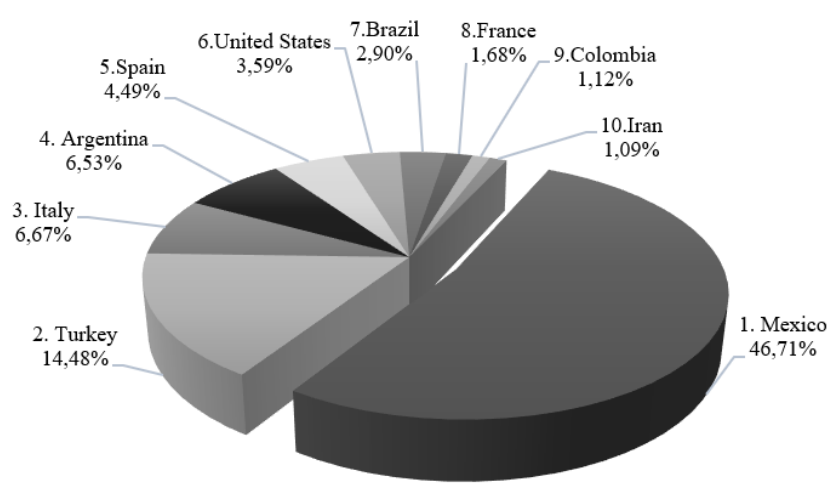

Figure 2. Visit Rates by Country

Referecence: Recorridos Virtuales México, 2020.

\section{Data collection: Netnographic Approach- TripAdvisor, Twitter}

In this study, the data obtained from two different social media types and the reflections of the virtual and real museum experience were examined. Data was collected through a netnographic approach that uses publicly available, forum media and ready-to-use information as a data source (Yildırım and

Research Article - This article was checked by iThenticate 
Şimşek, 2018: 229). Netnography, developed by Kozinets, form the understanding that social formations that interact in the virtual environment are functional and sincere human communities, has been adapted from traditional ethnography (Varnal1, 2013: 13-14). Netnography treats online communications not only as content but as social interaction, a set of meaningful expressions, and a cultural artifact. For this reason, netnography examines images, drawings, photography, sound files, edited audiovisual presentations, website creations, and other digital artifacts by not only looking at the words involved in social interactions but also the elements of the medium, the characteristics of the communicator, language, history, meaning and interaction forms (Kozinets, 2010; 2015). For this reason, it is possible to see the photos/images shared on Twitter and Tripadvisor as comments about spaces.

The shares of people who experience the Frida Kahlo museum in a real and virtual environment have been collected on social media. In 2020, before the pandemic, real museum experience shares were collected from shared images on TripAdvisor, and during the pandemic, virtual museum experience shares were collected from shared images on Twitter. From these images, the frequency of sharing certain points and places was determined. As a reflection of the real museum experience, the most shared points and places on TripAdvisor were listed, and the top five spots with the highest rate were determined. The determined points were processed in the museum plan. The same process was carried out on images shared on Twitter. Space syntax analysis was fulfilled on two plan planes containing data from virtual and real museum experiences.

\section{Data Analysis: Space Syntax Analysis}

Space Syntax Theory suggests that patterns of spatial preferences are the results of spatial configuration or geometry of space (Hillier and Hanson, 1984). These results define some forms of behavior. In this study, the interesting parts of a museum and the sharing behavior arising from these parts are discussed. The space syntax method provides important data in terms of defining the status of the configurative relations of the museum spaces considered in this respect. For this reason, integration analysis was performed at the points obtained from the collected data.

Integration value analysis is a graphical syntactic measurement that describes the relation of any space with all other spaces in a spatial organization and is based on depth in these relations (Peponis and Wineman, 2002; Hillier and Hanson, 1984). It means that the places with high integration value have strong bonds and are easily accessible in the whole spatial order. Spaces with low depth are spaces with high integration value. This value is an important indicator in predicting the density of space uses in Space Syntax Theory. In addition, places with high integration value are places with high accessibility and perceptibility (Yazıc1, 2018).

In this study, the use potentials and availability of the points obtained from the reflections of the real experience and virtual experience of the museum were determined by integration value analysis. The values of these points were compared. And, Correlations between the sharing rates and them were discussed.

Research Article - This article was checked by iThenticate

Copyright (C) The Turkish Online Journal of Design, Art and Communication 
The Turkish Online Journal of Design, Art and Communication - TOJDAC

ISSN: 2146-5193, Octobe 2021 Volume 11 Issue 4, p.1388-1402

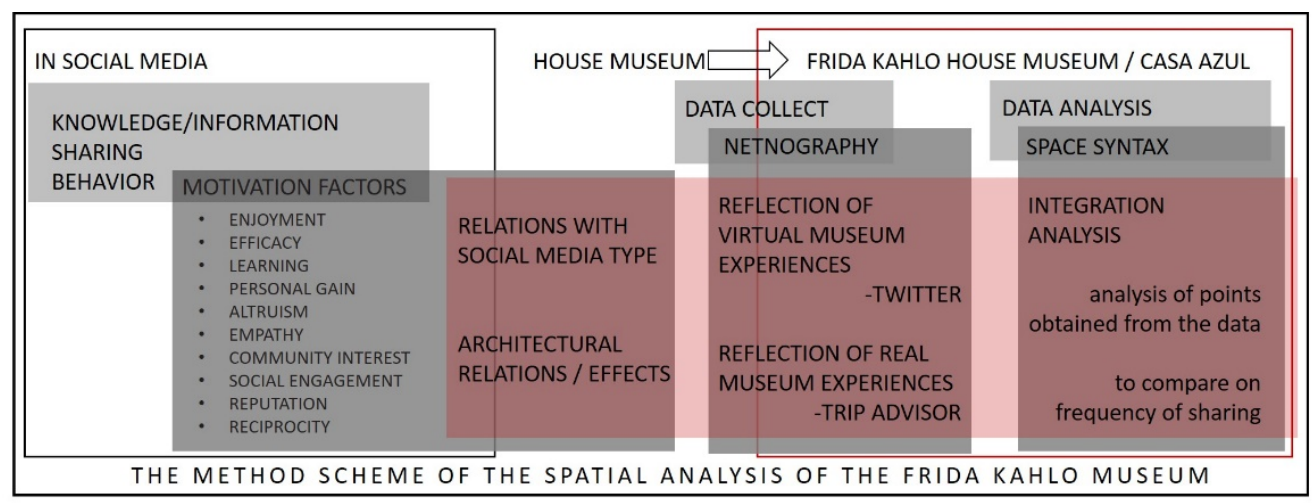

Figure 3. The Method Scheme of The Study

Reference: Prepared by authors.

\section{RESULTS: Comparison of Syntactic Analysis and frequency of sharing}

For the Frida Kahlo Museum, a real experience could not be carried out due to the pandemic, so first of all the information about the museum was collected by visiting the museum online. The museum is for numbering of spaces on the floor plan before determining how the house is used (Figure 4).

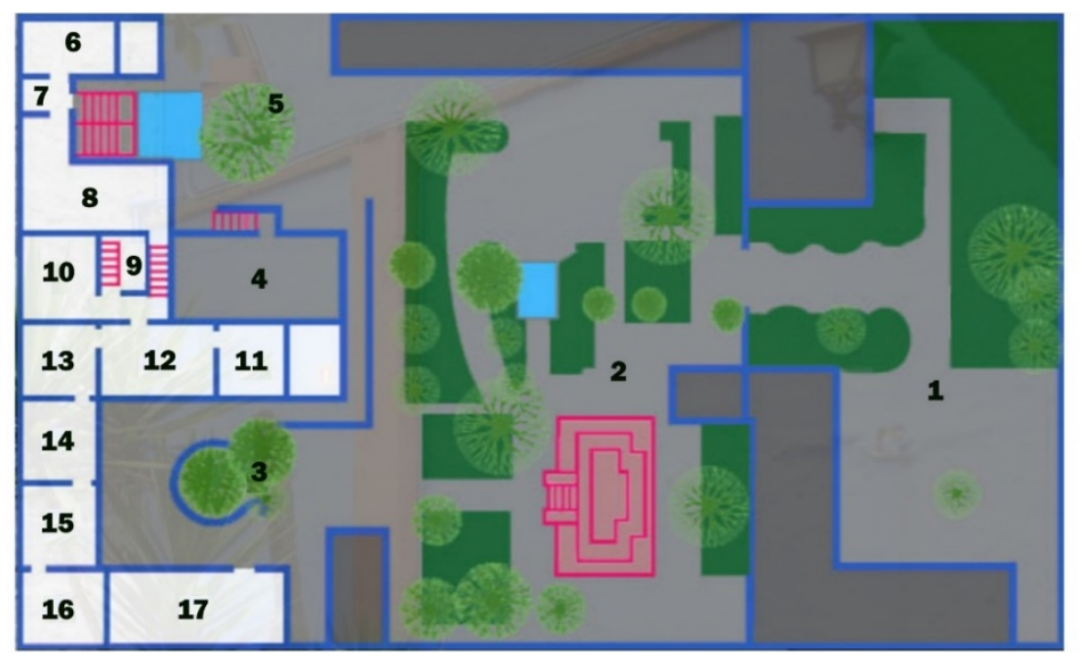

Figure 4. Numbering of Spaces

Reference: Retrived from the interface of virtual museum plan (URL-4).

Then the properties of the spaces belonging to the numbers were determined. According to this, space 1 is a courtyard space used as a cafe. Space 2 is the main courtyard of the house. Space 3 is the first experience place that visitors use as an entrance in to the real experience. Space 4 is an exhibition space used for different purposes on important days and occasions. Space 5 is the starting point during the virtual tour and is the continuation of the main courtyard. Space 6, 7, and 11 are the rooms used as bedrooms. Space 8 is the working area and library where Frida Kahlo produces her works. Space 9 is a transition area with a small sitting area. Space 10 and 12 are designed for kitchen and eating functions. Space 13, 14, 15, 16, and 17 are venues arranged as exhibition spaces within the house.

In the real experience, visitors entering the museum house start with space 3 then go on their trips with space 17. In the virtual experience, the system takes space 5 as the starting point and changes by clicking on the viewpoints instead of a fixed circulation, which venues will be visited depends on the free will of the visitor.

Research Article - This article was checked by iThenticate

Copyright (C) The Turkish Online Journal of Design, Art and Communication 
As a reflection of the real experience, the house-related posts made on TripAdvisor's social networking site were collected between January and March 2020. The images in the 4- and 5-star comments made to the Frida Kahlo museum are included in the study. The images of the people are excluded from the scope of the study. 29 images were disregarded out of 154 images. The left-out images did not have sufficient references to locate them and were excluded from the scope of the study. Accordingly, 125 images were included in the study.

As a reflection of the virtual experience, the images of the posts about the museum house were collected on the social networking site Twitter between March and May 2020. From the tweets searched with the \#fridakahlo hashtag, 174 images from 73 different accounts were obtained. From the tweets searched with the \#CasaAzul hashtag, 49 images from 15 different accounts were obtained. Accordingly, a total of 217 images were included in the study.

The data collected on TripAdvisor and Twitter were placed according to their location in the space where they were shared and according to the frequency of sharing (Figure 5).

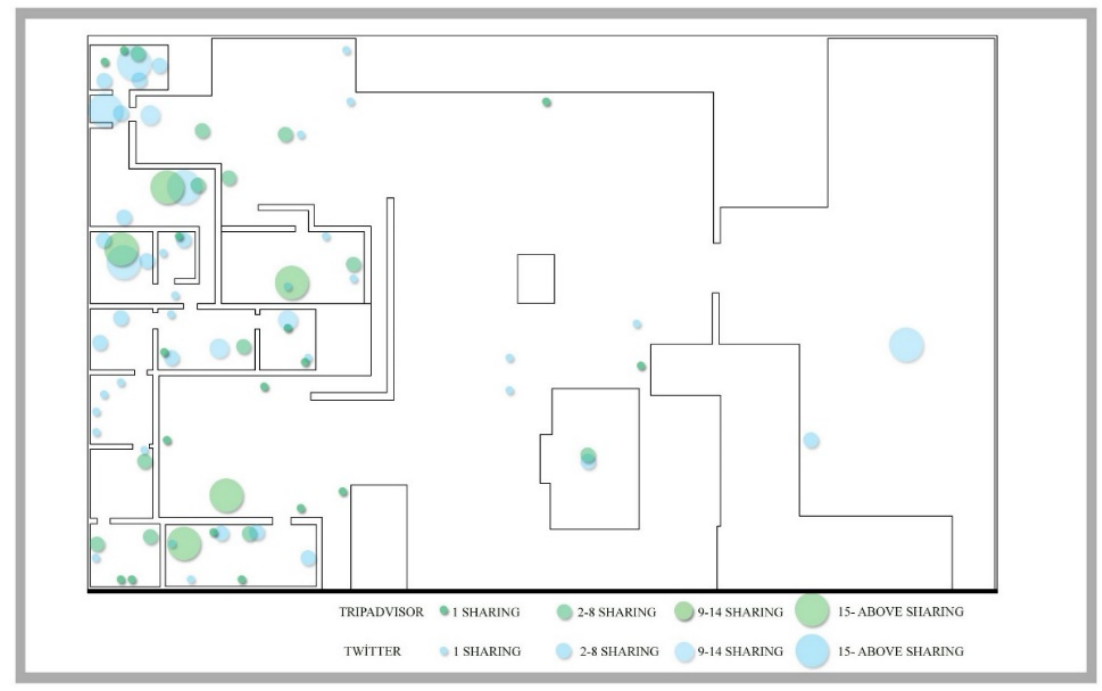

Figure 5. Density Map Based on Shared Space Reference: Prepared by authors.

According to the density map, the first 5 spaces of the images with the highest sharing frequency were determined. While the photos shared in the TripAdvisor application are placed inside the space, TA code is used, while the photos shared in the Twitter application are placed inside the space, the TW code is used. Among the 5 locations, the application from the most shared to the least shared is numbered next to the codes, respectively (Figure 6).

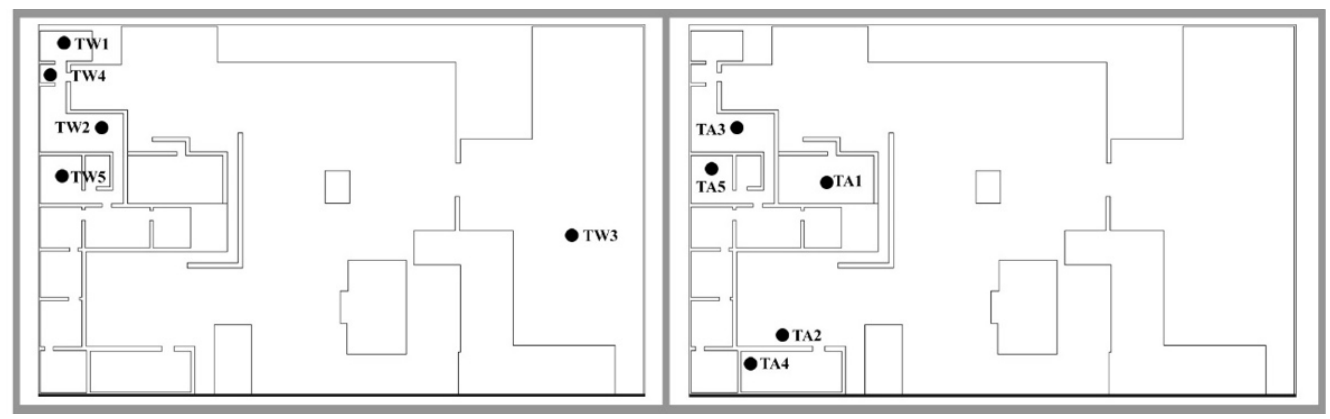

Figure 6. Top 5 Spaces by Sharing Frequency Reference: Prepared by authors.

Research Article - This article was checked by iThenticate 
Before determining the integration value of the 5 spaces obtained for both applications, the integration values of all the spaces were graphed using the Syntax 2D program (Figure 7). According to the results in the Syntax 2D program, the large courtyard, called space 2, has the highest integration value. The fact that the large courtyard space was not divided into sections and the garden elements not high enough to cut the field of view caused the integration values of this space to be high. According to the graph, the other courtyard, called space-1, has the second largest integration value on average. The interiors of the museum house have a lower integration value compared to space 1 and space 2 . This is because these spaces are divided into nested sections.

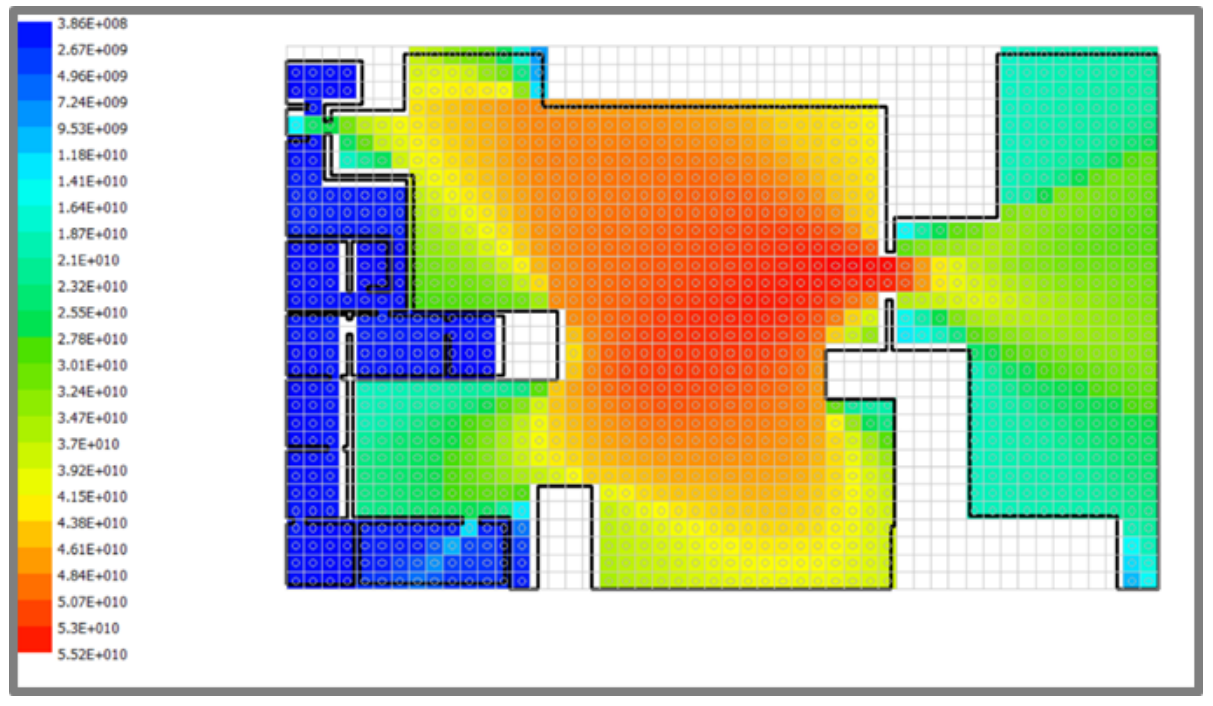

Figure 7. Graphic results of Syntax 2D analysis

Reference: Retrived from Syntax 2D.

Considering the integration values of the most shared spaces for the two applications, the most shared images for the Tripadvisor application are shown in the planned plane with the TA code. The integration values of the five points (space 3, 4, 8, 10, and 17) are as in Table 1. It was determined that the point with the highest integration value is TA1, which is the first in terms of sharing frequency. It was determined that the point with the lowest integration value is TA5, which is in fifth place. It is seen that there is great parallelism between the frequency of sharing and integration values in TripAdvisor, which are evaluated as the reflection of the real experience.

Table 1. Frida Kahlo Museum Sharing and Integration Values as Reflections of Real Experience

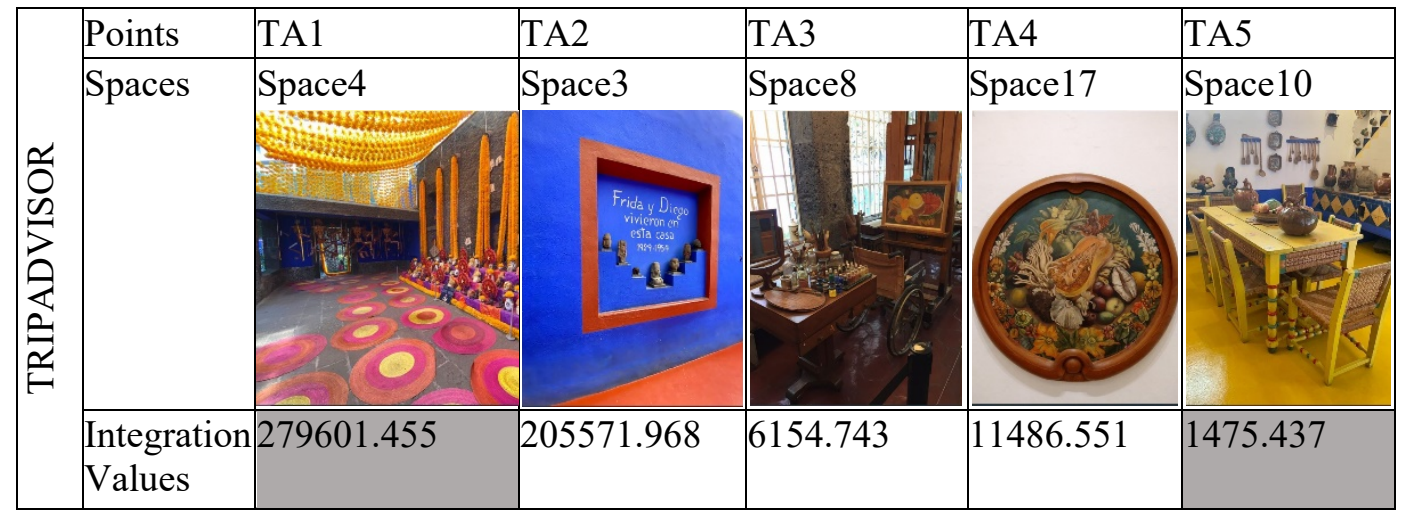

It was seen that the point that disrupts the parallelism between the frequency of sharing and integration value on TripAdvisor is the TA3 point. Herein, it has been observed that the spatial configuration, as

Research Article - This article was checked by iThenticate 
well as the semantic features of the points, are associated with sharing the space or artwork. TA3 point includes Frida's desk, painting equipment, and wheelchair. The sharing preferences of people; It is possible to say that the place was influenced by reasons such as having clues about how the artist produced with physical difficulties and objects that witnessed the realization of the magical moment in the creation of the work of art in the space.

It can be said that people observe the space-artist relationship in this way and they tend to share these observations with other purposes on social media with similar purposes such as efficacy and altruism. These reasons explain that it is the third most shared point regardless of the spatial configuration effect. TA1 point in space 4 with the highest sharing frequency is one of the spaces with the highest integration value. In addition to the integration value, open space activities in the space have a great influence on the sharing of this space. It can be understood that these temporary activities held at the museum attract interest and the wish to record it.The desire to testify and share the testimony of the event may have been accomplished for purposes similar to factors such as enjoyment, efficacy, altruism, reputation.

The fifth most shared point TA5 in space10 is one of the places with the lowest integration value in general. However, besides the spatial configuration, other features of the space made it interesting and worth sharing. The color of the space and the fact that space has tools for daily life may have made it among the top five shared points.

The most shared images on Twitter are located in the 1st, 6th, 7th, 8th and 10th spaces. For the Twitter application in the planned plane, the integration values of the five points determined by TW code are as in Table 2. It was determined that the point with the highest integration value is TW3, which is in the third place in terms of frequency of sharing. The point with the lowest integration value was determined to be the TW5 point in the fifth place. It is seen that there is no parallelism between the frequency of sharing and integration values in Twitter shares, which are evaluated as a reflection of virtual experience.

Table 2. Frida Kahlo Museum Sharing and Integration Values as Reflections of Virtual Experience

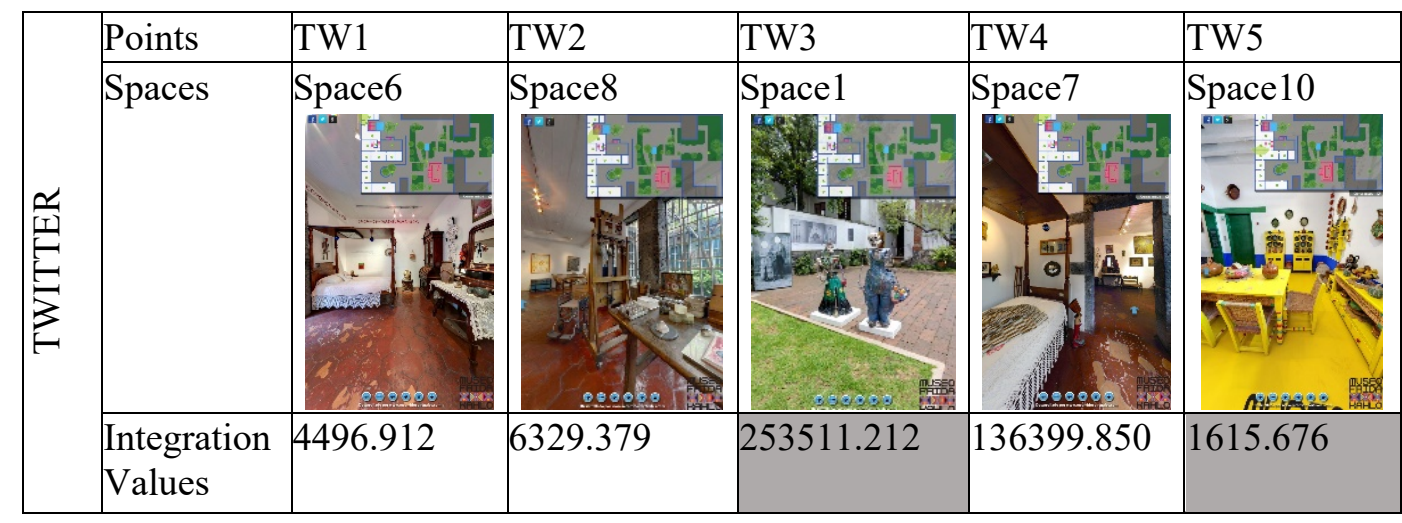

The highest sharing frequency point TW1 in space 4 is one of the spaces with the lowest integration value in general.it is one of the most interesting spaces that showcase Frida's personal, daily life. Particularly interesting objects in this place were its bed, mirror, showcase, colorful chair, and cabinet.

It was observed that the TW3 point in space 1, which is one of the places with the highest integration value, is the third most shared point. The point is located in the most distant part of the Museum from the least divided and concentrated exhibition areas has increased the integration value. In general, there are not many works to be observed in the virtual tour. However, the sculptures at TW 3 point attracted a lot of attention and were shared frequently. At this point, besides the spatial configuration, the 360degree camera angles offered by the virtual tour system of the Frida Kahlo museum are thought to be a factor directing the visitors. 
It was observed that the TW5 point in space 10, which is one of the places with the lowest integration value, is the fifth most shared point. It was seen that the point that reflects the real experience most is within this space. it is thought that this point is among the top five shared points with its features such as possession of belongings, tools and materials reflecting daily life and color status, as in the real experience.

\section{CONCLUSIONS}

This study is about testing the effect of real and virtual museum space experiences on the information sharing behavior of people on social media in the context of spatial configuration. In the study, the effects that encourage people to share information were examined. In this context, the effect of spatial configuration is tried to be understood by discussing museums at the intersection of art and architecture. In the quarantine process since March 2020, it was observed that virtual museums continue to be a part of information sharing behavior and experience. Accordingly, data collected from TripAdvisor and Twitter were examined to analyze the reflections of the virtual and real experiences of the Frida Kahlo Museum - which is also gathering high interest in Turkey.

After reviewing the general lines of the museum and introducing the places, by the data obtained from the TripAdvisor application and Twitter application, 5 points in the places with the highest sharing frequency were determined for both applications. Integration values of the determined points with the Syntax 2D program were determined to establish semantic connections between spatial configuration and sharing frequencies.

As a result, it has been observed that there is a significant connection between spatial configuration and frequency of sharing in real experienced spaces. However, with the spatial configuration, it has been determined that it guides the sharing behavior of the people in the semantic features of the spaces. In virtual experiences, no significant link was found between spatial configuration and sharing frequencies. Due to the fixed camera views in the virtual experience, it was seen that the semantic factors of the space came to the fore instead of the effect of the spatial configuration in the shares. It was seen that the artworks in the museum and the objects exhibiting the artist's life due to being a house museum were the reasons of the attraction and of shares.

In summary; the results of the study will be insufficient to precisely explain what effect the spatial configuration has on virtual and real experience. Likewise, it cannot provide precise results in explaining the relationship between study sharing frequencies and spatial configuration. Because the space has many more features than these components. However, with this study approach, a speculative approach was tried to be developed to the relationship between architecture and information sharing behavior. In this sense, the work carried out is important in terms of providing perspective for future studies. However, by expanding the scope of the study, this approach can be open to making general conclusions by analyzing more than one museum and more than five points.

\section{ACKNOWLEDGEMENT}

This work was produced in the 'Special Topics in Architectural Design' course given by Assoc. Prof. Dr. Mehmet Emin Şalgamcioğlu in spring 2020, Istanbul Technical University, and we are grateful to him for his contributions. We also thank Aura Castro and Felipe González from Recorridos Virtuales for their willingness to share their data with us.

\section{REFERENCES}

Alakurt, T. \& Keser, H. (2015). Bilgi Paylaşma Davranışları Ölçeği: Ölçek Geliştirme Çalışması. Kastamonu Eğitim Dergisi, 24(3), 1033-1054.

Appel-Meulenbroek, R. (2009). Knowledge sharing in research buildings and about their design. In Proceedings of the 7th International Space Syntax Symposium, Stockholm.

Research Article - This article was checked by iThenticate 
Bachelard, G. (2014). Mekânın Poetikası, trans. Alp Tümertekin, İthaki Publishing, İstanbul.

Benedikt, M. (1991). Cyberspace: Some Proposals. In Cyberspace, Cambridge MA: MIT Press.

Benedikt, M. L. (1979). To Take Hold of Space: Isovists and Isovist Fields. Environment and Planning B: Planning and Design 6: 47-65. https://doi.org/10.1068/b060047

Chang H.H. \& Chuang, S.S. (2011). Social capital and individual motivations on knowledge sharing: Participant involvement as a moderator. Information \& Management, 48 (1), 9-18. https://doi.org/10.1016/j.im.2010.11.001

Eco, U. (1989). The Open Work, Trans., Anna Cancogni, Cambridge MA: Harvard University Press.

Herrera, H. (2018). Frida: The Biography of Frida Kahlo. New York: Harper Perennial.

Hillier, B. \& Handson, J. (1984). Social Logic of Space. London: Cambridge University Press.

Hsu, M. H., Ju, T. L., Yen, C. H., \& Chang, C. M. (2007). Knowledge sharing behavior in virtual communities: The relationship between trust, self-efficacy, and outcome expectations. International Journal of Human-Computer Studies, 65(2), 153-169.

ICOM (2020, May 10). International Council of Museums http://icom.museum/

Irapoğlu, N. (2019) Mitolojik Analiz ve İletişim Bilimi Üzerinden Mimari Bir Okuma, Master Thesis, Karadeniz Technical University, Trabzon.

Kozinets, R, V. (2010). Netnograf: Pazarlamacinın Gizli Silahı. http://kozinets.net/wpcontent/uploads/2012/01/netnography-turkish.pdf

Kozinets, R. V. (2015). Netnography: Redefined. London: Sage.

Lee, C. S. \& Ma, L. (2012). News sharing in social media: The effect of gratifications and prior experience. Computers in human behavior, 28(2), 331-339.

Liu, Z. \& Jansen B.J. (2012). Almighty Twitter, what are people asking for? Proceedings of the Association for Information Science and Technology (ASIS\&T2012), Baltimore, MD, pp. 1-10.

Okuyucu, E, Çoban, G. (2021). Yeniden İşlevlendirilmiş Millet Hamami’nin Mekân Dizim Yöntemiyle Analizi. Turkish Online Journal of Design Art and Communication, 11 (1), 268-281. Retrieved from https://dergipark.org.tr/tr/pub/tojdac/issue/59046/810191

Peponis, J. \& Wineman J. (2002). Spatial Structure of Environment and Behaviour, in Handbook of Environmental Psychology, Ed. Robert B. Bechtel, Arza Churchman, New York: J. Wiley.

Recorridos Virtuales México (2020, May 12). E-mail interview with the company.

Şalgamcioglu, M.E. \& Cabadak, D. (2017). Permanent and Temporary Museum Spaces: A Study on Human Behavior and Spatial Organization Relationship in Refunctioned Warehouse Spaces of Karaköy, Istanbul. Proceedings of the 11th Space Syntax Symposium, Lisboa, pp 22-1-22-18

Stokols, D., \& Montero, M. (2002). Toward an environmental psychology of the Internet, Ed. Robert B. Bechtel, Arza Churchman, In Handbook of Environmental Psychology, 661-665, New York: J. Wiley.

Syn, S. Y. \& Oh, S. (2015). Why do social network site users share information on Facebook and Twitter? Journal of Information Science, 41(5), 553-569.

TDK, Türk Dil Kurumu Sözlüğü. https://sozluk.gov.tr/ (Erişim Tarihi: 09.05.2020)

Üstünipek, M. (2013). İstanbul Sanat Müzeleri Ve Sosyal- Medya: Twitter Örneği. Turkish Online Journal of Design Art and Communication, 3 (4), Retrieved from https://dergipark.org.tr/tr/pub/tojdac/issue/13015/156810

Uz, S. (2010). Kişisel Mekânların Müzeleştirilmesi: Burgaz Ada Sait Faik Abasıyanık Evi Örneği’nin İrdelenmesi, Master Thesis, Yı1dız Technical University, İstanbul. 
Van Dijck, J. (2013). The Culture of Connectivity: A Critical History of Social Media, New York: Oxford Press.

Varnal1, K. (2013). Dijital Kabilelerin İzinde. İstanbul: MediaCat.

Williamson, K., Qayyum, A., Hider P. \& Liu Y-H. (2012). Young adults and everyday-life information: The role of news media. Library \& Information Science Research, 34: 258-264.

Yazıcı, F. (2018). KTÜ Faik Ahmet Barutçu Kütüphanesi’nin Geçirdiği Mekansal Değişimlerin Mekan Kullanımına Etkisi, Master Thesis, Karadeniz Technical University, Trabzon.

Yıldırım, A. \& Şimşek, H. (2018). Sosyal Bilimlerde Nitel Araştırma Yöntemleri. 11. Ed. İstanbul: Seçkin Publishing.

Yıldızgörür, M. R. (2018). Sosyal Medya Güvenilirlik Algısının Bilgi Paylaşma Davranışıyla İlişkisi: Anadolu Üniversitesi Öğrencileri Örneği, PhD Thesis, Anadolu University, Eskişehir.

\section{ELECTRONIC RESOURCES}

URL-1 https://www.museofridakahlo.org.mx/en/the-blue-house/the-museum/ (Retrieved from: 07.05.2020)

URL-2 https://www.haberturk.com/htgastro/seyahat/frida-kahlonun-evine-sanal-bir-gezi-2658630 (Retrieved from: 07.05.2020)

URL-3 https://www.artsupplies.co.uk/blog/the-most-googled-artist-in-every-country-in-the-world/ (Retrieved from: 17.05.2020)

URL-4 https://www.recorridosvirtuales.com/frida_kahlo/museo_frida_kahlo.html (Retrieved from: 8.04.2020) 